\title{
Digital inclusion programs: the case of the Basque Country
}

\author{
Ricardo Palmeiro, Visitación Pereda \\ \& Luísa Aires
}

Abstract:

The progressive development of the Digital Age has given rise to a growing number of concepts related to individuals' experiences with their digital literacy, from the level of competence or lack thereof conceptualized in the digital divide, to the very concept of digital citizenship, essential today for participation in democratic societies. This article analyses the different interpretations made of these concepts with a view to clarifying their appropriate use according to the situations to be studied, understood as an intellectualized evolution of the realities and experiences lived by individuals and society. Since the beginning of the millennium, several national and regional digital inclusion projects began, encouraged by the European policies that aimed to alleviate the already existing digital gap. In this sense, the KZgunea program, the Basque government's digital inclusion project is analyzed as a paradigmatic case of the evolution of government programs and policies in favour of an adequate level of digital literacy that allows individuals to fully participate in all fields of today's increasingly digitized society. This report is part of a $\mathrm{PhD}$ thesis that analyzes digital literacy as an instrument of empowerment and social inclusion, to improve employability, and as a key to the construction of digital citizenship in the 21 st century.

Keywords:

digital citizenship; digital literacy; digital divide; digital competence; digital inclusion programs. 


\section{Programas de inclusão digital: o caso do País Basco}

Resumo: O desenvolvimento progressivo da Era Digital tem dado origem a um número crescente de conceitos relacionados com as experiências dos indivíduos e com a sua literacia digital, desde o nível de competências digitais ou a ausência destas, até ao próprio conceito de cidadania digital, hoje essencial para a participação nas sociedades democráticas. Este artigo analisa diferentes interpretações sobre estes conceitos, com vista a esclarecer o seu uso apropriado de acordo com as situações a estudar, entendidas como uma evolução intelectualizada das realidades e experiências vividas pelos indivíduos e pela sociedade. Desde o início do milénio iniciaram-se vários projetos de inclusão digital, nacionais e regionais, incentivados pelas políticas europeias que visavam reduzir o fosso digital já existente. Neste sentido, o programa KZgunea, o projeto de inclusão digital do governo basco, é analisado como um caso paradigmático da evolução dos programas e políticas governamentais orientados para a promoção da literacia digital que permite aos cidadãos participar plenamente em todos os campos de uma sociedade cada vez mais digitalizada. Este artigo incorpora uma parte da investigação em curso no âmbito de uma tese de doutoramento que analisa a alfabetização digital enquanto instrumento de empowerment e inclusão social e pretende, em última instância, contribuir para melhorar a empregabilidade, uma chave para a construção da cidadania digital no século XXI.

Palavras-chave: cidadania digital; alfabetização digital; exclusão digital; competência digital; programas de inclusão digital.

\section{Programas de inclusión digital: el caso del País Vasco}

Resumen: El desarrollo progresivo de la Era Digital ha dado lugar a un número creciente de conceptos relacionados con las experiencias de los individuos y con su alfabetización digital, desde el nivel de competencia o la falta de ella conceptualizado en la brecha digital, hasta el concepto mismo de ciudadanía digital, esencial hoy en día para la participación en las sociedades democráticas. En este artículo se analizan las diferentes interpretaciones que se hacen de estos conceptos, con el fin de clarificar su uso adecuado, en función de las situaciones a estudiar, entendidas como una evolución intelectualizada de las realidades y experiencias vividas por los individuos y la sociedad. Desde el comienzo del milenio se han puesto en marcha varios proyectos nacionales y regionales de inclusión digital, alentados por las políticas europeas destinadas a reducir la brecha digital ya existente. En este sentido, se analiza el programa KZgunea, el proyecto de inclusión digital del Gobierno Vasco (2012 y 2015), como un caso paradigmático de la evolución de los programas y políticas gubernamentales a favor de un nivel adecuado de alfabetización digital que permita a los individuos participar plenamente en todos los ámbitos de la sociedad actual, cada vez más digitalizada. Este informe forma parte de una tesis doctoral que analiza la alfabetización digital como instrumento de empoderamiento e inclusión social, para mejorar la empleabilidad y como clave para la construcción de la ciudadanía digital en el siglo XXI.

Palabras clave: ciudadanía digital; alfabetización digital; brecha digital; competencia digital; programas de inclusión digital.

\section{Programmes d'inclusion numérique: le cas du Pays basque}

Résumé: Le développement progressif de l'ère numérique a donné naissance à un nombre croissant de concepts liés à l'expérience des individus en matière de culture numérique, allant du niveau de compétence ou du manque de compétence conceptualisé dans la fracture numérique au concept même de citoyenneté numérique, essentiel aujourd'hui pour participer aux sociétés démocratiques. Cet article analyse les différentes interprétations de ces concepts en vue d'en clarifier l'usage approprié en fonction des situations à étudier, entendues comme une évolution intellectualisée des réalités et des expériences vécues par les individus et la société. Depuis le début du millénaire, plusieurs projets nationaux et régionaux d'inclusion numérique ont vu le jour, encouragés par les politiques européennes visant à réduire la fracture numérique déjà existante. En ce sens, le programme KZgunea, le projet d'inclusion numérique du gouvernement basque, est analysé comme un cas paradigmatique de l'évolution des programmes et politiques du gouvernement en faveur d'un niveau adéquat de culture numérique qui permette aux individus de participer pleinement dans tous les domaines de la société numérique d'aujourd'hui. Ce rapport fait partie d'une thèse de doctorat qui analyse la culture numérique en tant qu'instrument d'autonomisation et d'inclusion sociale, pour améliorer l'employabilité et comme clé de la construction de la citoyenneté numérique au XXle siècle.

Mots clés: citoyenneté numérique, culture numérique, fracture numérique, compétence numérique, programmes d'inclusion numérique. 


\section{Introduction}

Despite the increase in access to information and communication technologies, and despite the considerable development of the services offered on the Internet, especially in key social areas (work, training, politics and even leisure), researchers are aware of the considerable risk that inequalities between different sectors of the population could appear during this process (Area, 2012).

The most noteworthy effects of the digital divide, which particularly affect the exercise of citizenship, are of an indirect nature. There is still a considerable gap in the information and knowledge society between different segments of the population in terms of access to ICTs mainly due to problems of education and training. This is a source of inequality insofar as the above-mentioned services are beginning to be provided exclusively via the Internet (Tyner, Gutiérrez \& Torrego, 2015). There is therefore a real risk that these services would only be available to a part of the population, which is even more serious if one considers that public administrations and companies have begun a process of adjusting these services to the needs of the most frequent users, i.e. those who already have a high frequency of access. At the political level, this implies that the digital citizen would be positioned at a privileged level with respect to other citizens, with the consequent risk of creating inequalities at the level of political participation (Aparici, 2016).

States and regions have been developing the Treaties and Agreements that encourage the development of the Information Society in order to move towards new paths of digital democracy, such as the Lisbon Strategy (European Union, 2000).

In the initial years, the main focus was on access with the availability of Internet connection throughout the territories, as well as on the development of mobile telephony with Internet access. Gradually, investment was also made in the acquisition of digital skills and, to this end, digital inclusion programs were developed, most of them, with public funding (Travieso \& Planella, 2008). Nowadays, digital divide research emphasizes the Internet skills and the "tangible outcomes" (Van Deursen \& Helsper, 2015; Van Dijk, 2017; Van Laar, Van Dijk \& de Haan, 2017).

This paper deals with the case of the digital inclusion program KZgunea (2017) of the Basque Country, a region of northern Spain that has a great deal of autonomy and self-government, as well as decision-making capacity in strategic issues of its citizens' lives such as finance and health. The aim of the paper is to present the evolution of the program and to analyze the training pathways followed by users in recent years. The analysis of KZgunea program is also a part of a $\mathrm{PH}$. D. dissertation that seeks to compare two cases of digital inclusion programs: KZgunea (2017) and the Internet access centers of Alentejo (Portugal), while investigating the role of digital literacy in the full development of digital citizenship as a mechanism for reducing exclusion and promoting individual and community development. 


\section{Digital divide, Digital Literacy and Digital Competencies}

\section{The Digital Divide}

The increasing of access to digital technologies and the social and individual inequalities on the "haves and have nots" access to those technologies provided the arising of a new problem: the digital divide. Far from being a static problem, the digital divide has taken different features and meanings since its identification in 1999 to the present days (van Dijk, 2017).

A brief analysis of the digital divide research history let us identify the following features: 1) the research in digital divide is an interdisciplinary field; 2) digital divide was primarily studied in the areas of communication - mainly the access and use of digital media; psychology - in what concerns the attitudes, motivations, anxiety and technophobia in the digital media uses; education - highlights the digital literacy, digital competences and inclusion; sociology - above all the participation and social, cultural and techno-capital; economics- the innovations and its diffusion processes (van Dijk, 2017). In this research history, van Dijk (2017) enhances different phases in the history of digital divide phenomena:

. $1^{\text {st }}$ phase: 1999-2002. The research concentrated on sociological and economic perspective and was limited to the meaning of physical access to the technologies and its relations to sociocultural levels - age, gender, income, level of education, race.

. $2^{\text {nd }}$ phase: 2003-2015. A line of thought (van Dijk, 2005) defended the necessity to move the research focus from the access to the skills to use those technologies and the Internet and acknowledged the second-level divide. Digital divide research was above all descriptive; there was a lack of theory and of a deep understanding of the real impact of inequalities in the access and uses of digital technologies and the Internet. In this regard, van Dick $(2017,2)$ points out that until 2005 we can't find a tradition of media effects in digital divide research and adds that only after this date it was possible to identify the increasing of researches of access and its individual and social effects.

. $3^{\text {rd }}$ phase - currently van Deursen and Helsper $(2015,29)$ suggest a third digital divide level explained by "tangible outcomes". This phase concerns the inequalities in the "returns from internet use within populations of users who exhibit broadly similar usage profiles and enjoy relatively autonomous and unfettered access to ICTs and the internet infrastructure" (van Deursen \& Helsper, 2015, 30). The third-level divide translates the asymmetries in individuals' skills and attitudes to appropriate their internet access and use into "favorable offline outcomes" in their daily lives. So, nowadays, research on digital divide should determine who access the ICTs and Internet, what are the core and contextual skills individuals need to use them and the consequences of access and uses in individual offline lives (van Deursen \& Helsper, 2015; van Dijk, 2017; van Laar, van Deursen, van Dijk \& de Haan, 2017). 
It can be said that the digital divide will mean more development for countries, regions and people with better opportunities of access to the detriment of those others who have less. Indeed this difference will be made not only between countries, but also within each country, giving priority to populations with the best economic, political, social and cultural conditions. Digital divide is the product of the social breaches produced by the economic, political, social, educational, cultural, and gender inequalities, generational, geographical, etc. Thus, to overcome these barriers it is imperative to develop specific programs for vulnerable populations and in adult education, taking into account the characteristics of each, and bearing in mind that digital literacy entails lifelong learning.

\section{Digital Literacy}

The concepts of Digital Literacy and Digital Competence, although often used as synonyms, have different origins, meanings and areas of influence (Spante, Sofkova, Lundin \& Algers, 2018). Since Gilster (1997) popularized the concept of digital literacy, in the late 1990s, as a "basic preparation for the digital society", it has been identified by terms as diverse as: Multiliteracies (Jenkins, 2006; Cope \& Kalantzis, 2015; New literacies (Jenkins, 2006); Media and Information Literacy (UNESCO, 2008) (see Guttierrez \& Tyner, 2012). This diversity of conceptions results, in part, from the speed of scientific, technological and social innovations of the digital age and, for this reason, the understanding of their meanings necessarily involves the analysis of the literature produced and the consequent identification of the value of each perspective.

\section{Levels of Digital Literacy}

The systematic review of recent literature points to a great diversity of perspectives on the characterization of digital literacy, reflecting different research agendas and research contexts (Spante, Sofkova, Lundin and Algers, 2018). This diversity of definitions of digital literacy was grouped into two levels: conceptual and standardized conceptions (Santos, Azevedo \& Pedro, 2015). The conceptual definitions (e.g.: Gilster's, 1997, definition) cover, along with the specific skills, cognitive and socio-emotional dimensions that allow acting in digital contexts (such as awareness, understanding and critical reflection). In turn, the standardized, operational definitions describe what is involved in being digitally literate in terms of tasks, skills and performance levels. Following the studies of Ala-Mutka (2011), Santos, Azevedo and Pedro (2015) argue that these operational definitions are closer to a commercial perspective of concept application. On the other hand, Martin (2008) proposes three levels of development of digital literacy. Level I returns to basic digital skills, a prerequisite for digital literacy. Levels II and III refer to the specific contexts of use and transformation that coincide with the specific scope of digital literacy (see Santos, Azevedo \& Pedro, 2015). 
Martin's (2008) perspective on literacy is inseparable from two basic aspects: a) individual skills and b) social, situated, contextual and cultural dimension. In this regard, Santos, Azevedo \& Pedro (2015) refer that "Digital literacy is a quality that varies according to the individual's living conditions and that changes and develops over time, as it involves personal attitudes and qualities as well as knowledge and skills' (2015, 31).

Tyner adopting a holistic and critical perspective reinforces the idea that literacy is a broad, critical and complex social act. Tyner goes beyond the fragmented and operative logic embodied in lists of competences that the individual should possess and, alternatively, proposes the Multiliteracy Mandala. The mandala presents multiple prisms of analysis that configure the multifaceted nature of literacy/multiliteracy, in particular: a) cultural, historical, political, social, economic, environmental context; b) production, audience, circulation; c) narratives, instruments, aesthetics, texts; d) content (Tyner, 2011).

In developing their mandala, individuals can situate themselves in the roles of producers, audience, distributors or assume more than one of these roles simultaneously (prosumers), despite the specificities of each one. In this approach, Tyner (2011) promotes the systematization of critical thinking about the elements of literacy in the digital world and challenges the individual to question himself. In this challenge, the author stresses that access to schooling is a key factor, despite the numerous paths that are currently open in informal contexts that lead to the coexistence of various forms of literacy - oral, alphabetic, gestural, digital, among others (Tyner, 2011).

In summary, it is considered that digital literacy has a sociocultural and situational dimension due to its impact on the mediation of citizens' daily lives; it should be mediatic, due to the current relevance of the media; it is digital, given the importance of digital communication processes nowadays; it is multimodal or multidiscursive, due to the growing convergence between text, sound, image, video, animation (Gutierrez \& Tyner, 2012). The conjugation of these attributes should be promoted within the scope of a plural approach - in the sense of multiple; procedural - considering that literacy does not only refer to results, but, above all, to educational processes; evolutionary/ developmental - the individual is valued as a whole (cognitive, socioemotional); sociocultural - in addition to individual competences, complex social practices are also preferred (Goodfellow, 2011).

\section{Digital competence and digital literacy - a field of contradictions}

The concept of digital competence emerges at the end of the first decade of the 21 st century, thus presenting a shorter trajectory than that of digital literacy. However, we are facing a concept with a remarkable preponderance in specific contexts that are specified below (Spante, Sofkova, Lundin \& Algers, 2018). 
Some documents produced by the European Commission (e.g. Digital Agenda Scoreboard 2011; reports) propose the integration of digital competence into the group of eight key competences for lifelong learning. These documents relate digital competence to the use of technologies in professional settings, particularly in education. Santos, Azevedo and Pedro (2015) refer, in this regard, that in the Digital Agenda Scoreboard 2011 report (European Commission, 2011), it is possible to identify two main factors of digital competence: a) environment; b) individual competence. The first factor refers to the availability and accessibility of ICTs; the second calls for basic skills and the application of knowledge in different contexts and the critical, reflective and ethical attitudes of individuals in the creative use of ICTs and the Internet. This perspective is in line with the results of the study by Spante, Sofkova, Lundin and Algers (2018) in which the authors highlight the fact that, within the scope of scientific research, the approach to digital competence is minority and, when this is verified, it often refers to the professional development of teachers, namely the capacities to promote ICT-mediated learning activities.

A field of tension and contradictions emerges from the comparison of the concepts of digital literacy and digital skills, based on the research produced. Santos, Azevedo and Pedro (2015) and, later, Spante, Sofkova, Lundin and Algers (2018) highlight these paradoxes in publications of diverse nature. Some strategic documents of the European Commission point to the dependence of one concept on the other, sometimes with the inversion of this dependence in the same document. Santos, Azevedo and Pedro $(2015,34)$, based on the analysis of some European Commission documents (2011), such as a working paper, stress that, in this document, digital literacy is seen as "skills required to achieve digital competence". On the other hand, the Digital Agenda Scoreboard 2011 states that "digital competence can be considered as digital literacy in the broad sense" (European Commission, 2011)" (idem). The authors also stress that it is possible to identify opposing views in the latter document.

In general, it is considered that digital competence concept means the ability to use digital technologies in the context of work, leisure and communication (From, 2017). If we opt for a more specific definition, in line with Ferrari (2012), digital competence refers to the set of skills and competences needed to perform tasks, solve problems, create and share knowledge in a critical, ethical and autonomous manner in different contexts (work, participation, leisure and personal development).

Unlike the concept of digital literacy, digital competence is more present in publications from continental Europe and Latin America, namely in strategic and political documents (Spante, Sofkova, Lundin \& Algers, 2018), and most of these documents associate the concept with educational contexts, namely students and teachers. 


\section{KZgunea: The beginning of the project}

European institutions developed politics of digital inclusion that drived to specific national ways of concretion and various technological and information capacity building projects in different European regions. The aim of these projects was to promote the acquisition of digital skills by individuals, who were largely lacking in any type of training, which led to the existence of an enormous digital gap from the very beginning of the implementation of new technologies in social and administrative processes.

One of these projects was created in the Basque Country, the so called KZGunea, is present in most of Basque municipalities since more than fifteen years. It offers access and training in new technologies to its users and has evolved in its objectives, its methodology and the way it has been presented to society, reflecting the conceptual changes that have also been happening over the years.

KZgunea was born in 2001 as a project to minimize the digital divide (actually called digital inclusion effect). The panorama described in government program Basque Plan in the Information Society, showed deficiencies in computer equipment in households and businesses, which were treated with subsidies for the purchase of personal computers (1995-2000), a project called "Conéctate" (Conect yourself); training for companies, mainly small and medium-sized enterprises (1995 to present); citizen's lack of knowledge of the basic tools available to a personal computer and of the possibilities offered by the Internet in the search for information.

\section{KZgunea Project Start-up}

KZgunea (Citizen, connect!) was launched in 2001 with two key objectives: citizens can be able to connect to the Internet in public places, using equipment and communications networks made available by the Basque government; people should have basic training to get started on the Internet and use the basic resources of a personal computer, all the personnel dedicated to the training and management of the centers are hired as an integral service. Also all services should be free of charge for the users.

\section{Participating Institutions}

From the beginning several institutions participated in the implementation of this program. In addition to the Basque government departments involved, other institutions participated: town halls and other entities, public and private institutions, that from the beginning were incorporated into the project as users of the services according to the needs of each organization. 
Figure 1: KZgunea place within Basque Government organigram.

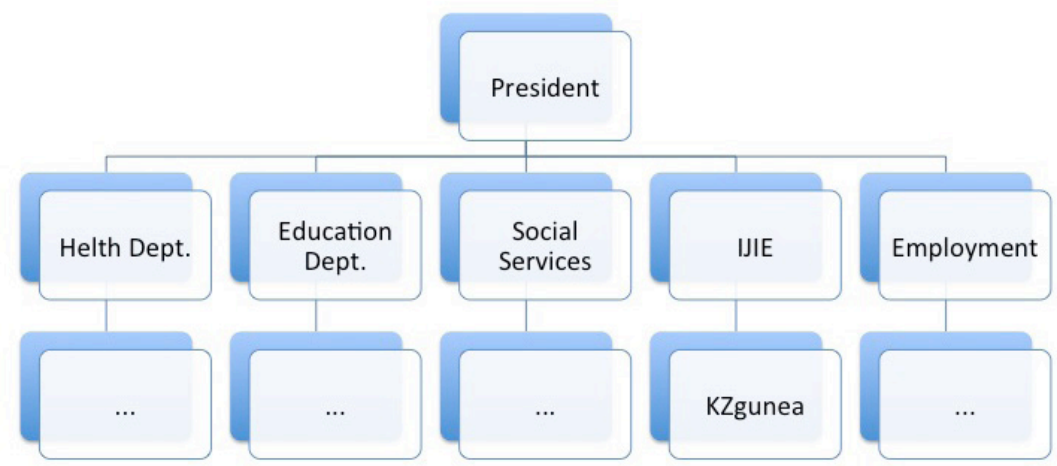

Source: authors (2018)

\section{Stages of the project development}

\section{Deployment}

In 2001, the first 20 centers were opened in the same number of municipalities. Throughout 2002, 2003 and 2004, almost all the town councils in the Basque Country (250), more than 265 centers, were reached, with Internet access with a bandwidth of more than $4 \mathrm{Mbs}$, due to the fact that more than one center was set up in some 7 towns with an above-average population. The number of personal computers available exceeded 2.500 terminals, all equipped with free software to support the operating system (Linux) and office automation (Libre office).

The "approach" of each of the municipalities and associated centers is based on an active period of training for the "target groups", which included about 3 months of intensive activity. This target group includes groups such as the unemployed, adults, and citizens who work at home, without excluding anyone interested in any of the services.

As a guideline, KZgunea has had 436,739 people registered until December 2018 (in a 2.200.000 population in the Basque Country) with some different profiles: assets, 43,4\%; unemployed, 25,9\%; students, 12,6 \%; retired: 9,7\%; household chores: 8,2\%; not determined: $0,2 \%$.

After the intensive period, each center is stabilized in two main models: permanent presence of full-time or part-time educators, which means the daily opening of the premises; presence at the request of the citizens of the city council, for specific training needs or updating of basic training. 
This territorial deployment treatment scheme has been maintained to date, with hardly any reduction in the number of operational centers and the technical equipment available. This situation, for budgetary reasons, as a consequence of the times of the economic crisis of universal geographical scope, has led to a reduction in human resources that has never exceeded 30\%.

Figure 2: KZgunea's general statistics 2001-2017.

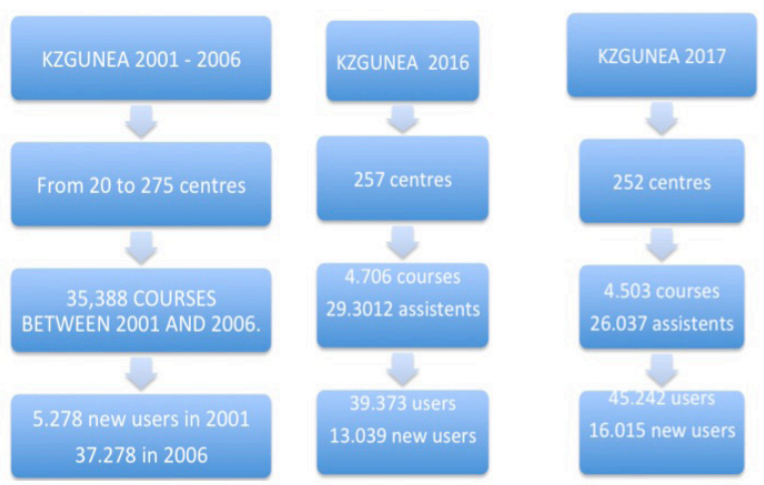

Source: authors from information given by Basque Governement (2018)

\section{Training content}

The initial objective was centered on basic citizen training, with a single classroom module. In the first 3-4 years, more specific courses were incorporated, almost all of them at the request of the citizens. In 2005, training in e-government services was incorporated, in collaboration with public agencies that offered this services. In 2007, the need arose to collaborate with the Department that manages the Information Society, which manages digital skills qualification tests (IT-Txartela), the results of which are used as assessment criteria in personnel selection processes, essentially in public administrations.

Since 2012, a process of revision of the training scheme has been initiated, with the fundamental objective of reorienting and adapting the project's training services portfolio.

\section{Organization and Management}

KZgunea set up a project management and supervision team that is divided into three main areas: Infrastructures and systems, quality and contents, operational deployment.

The subcontracted resources associated with the three areas are located in: a central Technical Office that directly manages the first two areas and where the resources 
associated with their work; an Operational Deployment group that is spread throughout all the centers in operation. Educators carry out their functions in the centers, especially those that are open on a daily basis. This group is directed and organized by a team of coordinators who supports them in their daily work of interlocution with city councils as well as in technical and operational problems. There are special situations in which educators dedicate a percentage of their time in the elaboration and maintenance of contents, courses, audiovisual material, etc.

\section{Training}

At the beginning of the project, the training provided was only face-to-face and very basic. The aim was for the user to become familiar with the PC and learn to navigate and search for information. In 2008, the catalog of courses of KZgunea was expanded in order to add the new tools available on the Internet, such as social networks, eAdministration procedures, etc. KZgunea had more than 100 courses in its catalog so the maintenance of courses was complicated. It was also found that there was no homogeneity in the centres with the training offered to users. Therefore, in 2014 it was decided to create a Training Plan adapting the course catalog to real needs.

\section{KZgunea Training Plan}

The Plan was launched in January 2015. From this date on, KZgunea not only offers on-site courses, but also creates new training modalities such as the following: Distance Learning, Self-Training, Talks and Tutorials.

Figure 3: KZgunea training plan launches in 2015.

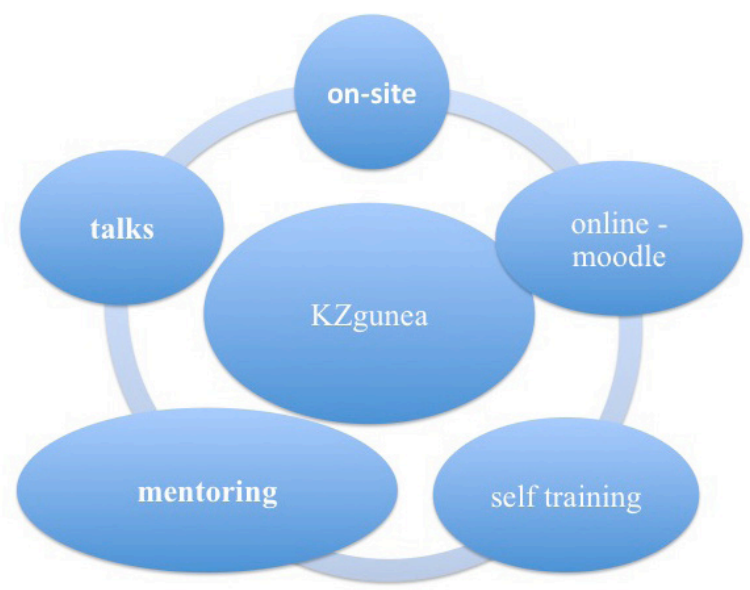

Source: authors (2018) 


\section{Face-to-face Courses}

All the contents of the courses are on the KZgunea Moodle platform. No prior registration is required to enter. There are different level courses (figure 4) and with diverse durations- from 2 hours to 20 hours. Each session of the courses is 2 hours a day, led by the teaching staff. In the long term courses there are theoretical and practical sessions led by the teaching staff and there are also a few hours of exercises in which the users will practice the skills they have learned. In face-to-face training, an itinerary has been designed to advise users.

Figure 4: Training itineraries. Source: authors (2018)

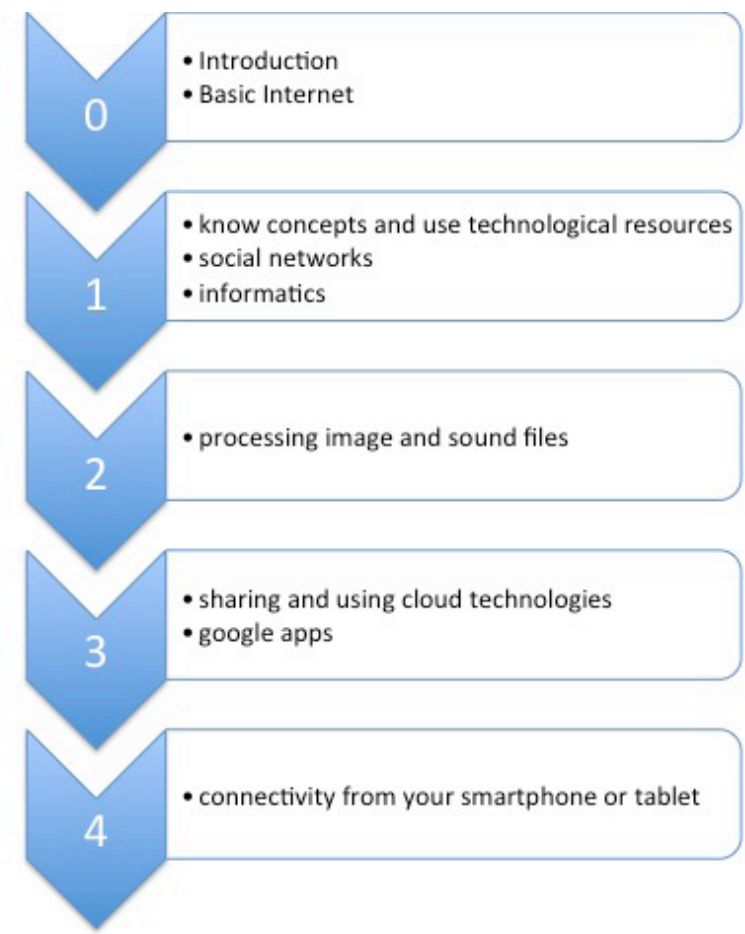

Source: authors (2018)

\section{Distance Learning Courses, Self-Training Courses, Pedagogical Assistant and New devices}

There are sessions with a fixed duration but once that time has elapsed they are not closed, giving users the comfort of doing the lessons whenever they want, with a weekly tutorial (Skype) that is held to solve any questions. Distance courses have a 6 structure levels, being the basic one related to safe purchases in Internet, storage in 
the cloud, and job search. In level 1 are taught word processors, spreadsheet and the correct use of social networks. In the second level are taught image and video editing. In level 3 Google applications are dealt with, and in the fourth level the Android system is deepened. In the last level creation of blogs is taught.

There are also self-training courses that don't require registration in KZgunea and are freely accessible from the Moodle Platform. Courses are offered relating to the mail system promoted by the Basque government (Metaposta), issues relating to citizen participation, e-government, public health portal, among other applications related to government.

The pedagogical assistant will show which courses are best adapted to the technological needs of the user. Users also demand that the training can be done on their own device, not on a computer "borrowed" for the course, following the BYOD (Bring Your Own Device) philosophy.

The informal talks, which last about two hours, deal with aspects such as online shopping, updating devices, introduction to new technologies for seniors, avoiding over-exposure to technologies, among other aspects.

What is certain is that the program continues to move forward and to explore the new frontiers of digital literacy. Faced with those who say that this type of program does not make sense because most of users have a device with access to the Internet, Kzgunea continues to opt for training so that no citizen is left behind.

\section{Conclusions}

The development of information and communication technologies has grown a lot in the last few decades. The services offered on the Internet in different areas are growing. However, access to these services is not the same for everyone, so we could be in the presence of a new source of inequality between different sectors of the population. Some people may see their exercise of citizenship curtailed due to the impossibility of accessing services offered on the Internet related to key social areas. People need education and training to acquire new knowledge and skills related to literacy and digital skills. This need is especially important in the most vulnerable groups and needs to be addressed both in adult education and in active job search programs, from a lifelong learning perspective. States and regions have developed different programs based on agreements for the purpose of digital democracy.

Thus, it is possible to speak of the digital divide as an interdisciplinary field of study and research because it involves different areas such as communication, psychology, education, sociology, etc. In fact, the introduction of a new type of language (written language, audiovisual language, digital language) has always required education and training for its correct use, that is to say, for reading and writing in this language. This 
makes it necessary to introduce the concepts of Digital Literacy and Digital Competence. Although these terms are often used as synonyms, they have different origins, meanings and areas of influence.

There are many different perspectives on digital literacy, but digital literacy is considered to have socio-cultural and situational dimensions, because it has an impact of citizens' daily life. Literacy refers, above all, to the educational process, not just to outcomes, and is not reduced to the actual capacity to use digital resources. Digital literacy is more present in English-language research and in Asia and is more linked to issues related to changing educational practices and the development of education systems.

The digital expression of competences has a shorter trajectory than that of digital literacy, since it only arose at the end of the first decade of the 21 st century and is integrated into the concept of competence in Education. It is more present in research in continental Europe and Latin America related to educational contexts, i.e. students and teachers. The concept of digital competence is linked to the ability to use digital technologies in different contexts. In this case, the focus is on the person who is or is not competent in the use of digital technologies. The expression "digital competence" incorporates several specific dimensions that need to be worked on.

KZgunea is a project created in 2001 to develop the digital competence of the citizens of the Basque Country. Like other similar projects, this one has gone through different stages with some changes incorporated in each one of them related to objectives, contents, participants, implied institutions, etc.

To achieve the goal of full digital citizenship, the governments and institutions involved should continue to promote digital inclusion programs or other types of training to ensure that all citizens can participate actively in the society of the 21 st century.

The dynamics of the project itself portrays the evolution from a perspective more focused on the development of the acquisition of digital competence, at first, towards a more global and integrating vision of the individual and social perspective, digital literacy, for the sake of achieving full digital citizenship.

\section{References}

Ala-Mutka, K. (2011). Mapping Digital Competence: Towards a Conceptual Understanding. JRC Technical Notes. Available: http://ftp.jrc.es/EURdoc/JRC67075_TN.pdf.

Aparici, R. \& García-Matilla, A. (2016). How has Media Literacy evolved in the last 35 years. Thinking about the future. Espacios en blanco, 26, 35-57.

Area, M. (2012). Sociedad líquida, web 2.0 y alfabetización digital. Aula de innovación educativa, 212, 5559.

Cope, B. \& Kalantzis, M. (2015). A Pedagogy of Multiliteracies. London: The London Group. 
European Comission (2011). Digital Agenda Scoreboard 2011 report. Available: https://joinup.ec.europa.eu/document/eu-digital-agenda-scoreboard-2011.

European Union: (2000). Presidency Conclusions. Lisbon European Council. Available: de: http://www. consilium.europa.eu/uedocs/cms_data/docs/pressdata/en/ec/00100-r1.en0.htm.

Ferrari, A. (2012). Digital competence in practice: An analysis of frameworks. Seville: Joint Research Centre, Institute for Prospective Technological Studies.

From, J. (2017). Pedagogical digital competence-between values, knowledge and skills. Higher Education Studies, 7 (2), 43-50.

Gilster, P. (1997). Digital Literacy. Hoboken, USA: John Wiley and Sons, Inc.

Gobierno Vasco. Presidencia del Gobierno (2012). Plan Euskadi de la Sociedad de la Información. Recuperado de: http://www.euskadi.eus/gobierno-vasco//contenidos/plan_gubernamental/ plan_12/es_plan_12/plan_12.html.

Gobierno Vasco (2015). Agenda digital de Euskadi 2020. Vitoria-Gasteiz: Eusko Jaurlaritza.

Goodfellow, R. (2011). Literacy, literacies and the digital in higher education. Teaching in Higher Education Volume 16 (1), 131-144.

Gutiérrez, A. \& Tyner, K. (2012). Educación para los medios, alfabetización mediática y competencia digital. Comunicar, 19 (38), 31-39.

Jenkins, H. (2006). Convergence culture. Where old and new media collide. New Yor, USA: New York University Press.

KZgunea (2017). Aprendizaje digital para el bien común. Memoria 2017. Vitoria-Gasteiz: Gobierno Vasco.

Martin, A. (2008). Digital literacy and the 'digital society'. In C. Lankshear \& M. Knobel (Eds.), Digital literacies: Concepts, policies \& practices. New York: Peter Lang, pp. 151-176.

National Telecommunications and Information Administration. United States Department of Commerce (1999). Falling Through the Net:Defining the Digital Divide. Available: https://www.ntia.doc.gov/ report/1999/falling-through-net-defining-digital-divide.

Santos, R., Azevedo, J. \& Pedro, L. (2015). Literacia(s) digital(ais): definições, perspetivas e desafíos. Media \& Jornalismo, 15 (2), 17-44.

Spante, M., Sofkova, S., Lundsin, M. \& Algers, A. (2018). Digital competence and digital literacy in higher education research: Systematic review of concept use. Information \& Communications Technology in Education, 5. Available: https://doi.org/10.1080/2331186X.2018.1519143.

Tyner, K. (2011). Media literacy and the promise of school change. Journal of Media Literacy, 57 (2).

Tyner, K., Gutiérrez, A. \& Torrego, A. (2015). Multialfabetización sin muros en la era de la convergencia. La competencia digital y "la cultura del hacer" como revulsivos para una educación continua. Profesorado: Revista de curriculum y formación del profesorado, 19 (2), 41-56.

Van Deursen, A.J.A.M. \& Helsper, E.J. (2015). The Third-Level Digital Divide: Who Benefits Most from Being Online? Communication and Information Technologies Annual (Studies in Media and Communications), 10, $29-52$.

Van Dijk, J. (2005). The deepening divide: inequality in the information society. London: Sage. 
Van Dijk, J. (2017). Digital Divide: Impact of Access. The International Encyclopedia of Media Effects. Twente: University of Twente.

Van Laar, E., Van Deursen, A. J. A. M., Van Dijk, J. A. G. M., \& de Haan, J. (2017). The relation between 21st-century skills and digital skills: A systematic literature review. Computers in human behavior, 72, 577-588.

Ricardo Palmeiro University of Deusto (Spain)

Email: ricardo.palmeiro@deusto.es

Orcid: https://orcid.org/0000-0002-4504-4707

Visitación Pereda

University of Deusto (Spain)

Email: visi.pereda@deusto.es

Orcid: https://orcid.org/0000-0003-4092-6898

Luísa Aires

Universidade Aberta (Portugal)

Email: luisa.aires@uab.pt

Orcid: https://orcid.org/0000-0001-5649-276X

\section{Correspondência}

Luísa Aires

Universidade Aberta, Departamento de Educação e Ensino a Distância

Rua da Escola Politécnica, 147, 1269-001- Lisboa

Data de submissão: Novembro 2018

Data de avaliação: Janeiro 2019

Data de publicação: Setembro 2019 